\title{
PERILAKU HIDUP BERSIH DAN SEHAT ERA NEW NORMAL
}

\author{
Siti Husnul Hotima \\ Progam Studi Ilmu Administrasi Niaga \\ Sekolah Tinggi Ilmu Adminisrasi Pembangunan Jember \\ *Email: sitihusnul.stiapjbr@gmail.com
}

\begin{abstract}
ABSTRAK
Pandemi Covid-19 telah mengubah banyak hal dalam sekejap, Untuk itu dalam merespon di butuhkan perubahan dalam perilaku hidup bersih dan sehat era new normal.. Dalam menerapkan fase New Normal, dimana new normal bukanlah kondisi dimana tidak ada lagi virus Covid-19 untuk itu diperlukan sosialisasi kepada masyarakat dengan tujuan untuk memutus rantai penyebaran virus Covid-19.

Pengabdian dilakukan kepada penerima Program Keluarga Harapan (PKH) Desa Jatimulyo Kecamatan Jenggawah. Metode yang digunakan melalui Sosialisasi kepada masyarakat. Tujuan pengabdian dosen kepada masyarakat sebagai bentuk transfer pengetahuan tentang cara-cara penerapan perubahan perilaku sebagai upaya preventif Covid-19.

Hasil yang didapatkan dalam pengabdian ini adalah Peserta

Sosialisasi memiliki pengetahuan dan kemampuan untuk menerapkan dan memotivasi serta beradaptasi terhadap anggota keluarga, masyarakat sebagai pelopor dalam melakukan perubahan perilaku hidup bersih dan sehat era new normal..

Kata Kunci : Perilaku Hidup Bersih dan Sehat, Era New Normal, Covid-19.
\end{abstract}




\section{Analisis Situasi}

Pola penerapan hidup bersih dan sehat merupakan bentuk dari perilaku berdasarkan kesadaran sebagai wujud dari pembelajaran agar individu bisa menolong diri sendiri pada masalah kesehatn ataupu ikut serta dalam mewujudkan masyarakat yang sehat di lingkungannya. Perilaku Hidup Bersih dan Sehat merupakan bentuk dari upaya untuk memutus rantai pandemi Covid-19 Sosialisasi banyak dilakukan dengan melalui media komunikasi, pemberian berita, serta adanya pendidikan agar terjadinya peningkatan pada pengetahuan, perubahan sikap, dan perilaku melalui metode pendekatan dari pimpinan, membina suasana dan juga melakukan gerakan memampukan diri pada kelompok masyarakat. Kondisi ini sebagai wujud pencerminan yang berguna untuk membantu masyarakat dalam mengenali dan mengetahui serta mengatasi masalah yang terjadi pada individu dalam tatanan rumah tangga. Tujuannya tidak lain adalah agar terbentuknya masyarakat yang menerapkan cara kebiasaan hidup yang sehat pada kesehariannya yang merupakan upaya dalam meningkatkan derajat kesehatannya pada tatanan rumah tangga atau lingkungan masyarakat (Kemenkes RI, 2011).

$$
\text { Kesehatan merupakan }
$$
kondisi dimana kita berada jauh atau terbebas dari penyakit. Merupakan suatu yang mahal jika dibandingkan dengan hal-hal yang lain. Bagaimana tidak, harta yang melimpah, memiliki paras tampan atau cantik, memiliki badan tegap dan gagah, semuanya itu akan sirna dengan sekejap jika kita terserang penyakit atau tidak sehat. Dengan penyakit harta bisa habis digunakan untuk berobat, paras tampan atau cantik berubah menjadi pucat dan tidak enak untuk dipandang, badan yang tegap dan gagah seketika roboh dikarenakan lemas dan lesu akibat kondisi tubuh yang menurun drastis.

Beginilah alur kehidupan, semuanya menjadi seimbang. Ada sehat dan ada sakit, kita tidak akan selalu sehat dan kita juga tidak akan selalu sakit. Semuanya itu bagaimana kita bisa menjaga diri untuk terhindar dari penyakit sehingga kesehatan itu 
merupakan hal yang mutlak harus dijaga.

Mencegah sakit adalah lebih mudah dan murah dari pada mengobati seseorang apabila jatuh sakit. Salah satu cara untuk mencegah hal tersebut adalah dengan bergaya hidup sehat. Gaya hidup sehat adalah segala upaya untuk menerapkan kebiasaan yang baik dalam menciptakan hidup yang sehat dan menghindarkan kebiasaan buruk yang dapat mengganggu kesehatan. Dengan semakin banyaknya penderita penyakit tidak menular (degeneratif) seperti jantung, tekanan darah tinggi, kanker, stress dan penyakit tidak menular lainnya yang disebabkan karena gaya hidup yang tidak sehat, maka untuk menghindarinya kita perlu bergaya hidup yang sehat

Hingga saat ini perilaku hidup bersih dan sehat menjadi satu perhatian khusus yang dialkukan oleh pemerintah dalam menerapkan fase New Normal, dengan melonggarkan pembatasan sosial, dengan tujuan Pertama untuk memulihkan ekonomi setelah sekitar tiga bulan pemerintah mengeluarkan kebijakan pembatasan sosial, tinggal dan beraktifitas di rumah. Kedua untuk memutus rantai penyebaran virus Covid-19. Pada fase New Normal diharapkan semua bisa produktif dan semangat dalam melakukan kegiatan ekonomi meskipun pandemi Covid-19 tetap ada dan cenderung meningkat.

Di masa pandemi Covid-19, banyak masyarakat yang mencari informasi mengenai cara mencegah virus korona dan usaha meningkatkan kekebalan tubuh. Sejak kasus pertama pada 2 Maret 2020 di Indonesia, hingga kini terus terjadi peningkatan jumlah positif Covid-19. Pemerintah membentuk Gugus Tugas Percepatan Penanganan Covid-19 untuk menekan penyebarannya. Namun, sebagai individu, kita juga perlu berbuat sesuatu untuk mencegah penyebaran virus ini.

Perilaku Hidup Bersih dan Sehat (PHBS) merupakan semua perilaku kesehatan yang dilakukan atas kesadaran sehingga anggota keluarga atau keluarga dapat menolong dirinya sendiri di bidang kesehatan dan dapat 
berperan aktif dalam kegiatankegiatan kesehatan di masyarakat (Proverawati \& Rahmawati 2016).nMenurut Conner dan Norman (2009) dalam Achmadi (2013) bahwa perilaku kesehatan adalah serangkaian tindakan yang dilakukan untuk mencegah atau mendeteksi gejala awal dari sebuah kejadian penyakit untuk meningkatkan kesehatan dan kesejahteraan. Pelaksanaan program perilaku hidup bersih dan sehat dikelompokkan menjadi 5 tatanan yaitu PHBS di sekolah, di rumah tangga, di tempat kerja, tempattempat umum dan PHBS diinstitusi kesehatan. Pelaksanaan PHBS di sekolah dapat dimulai dari hal yang sederhana seperti mencuci tangan dengan sabun.

Meningkatnya perilaku cuci tangan yang benar (cuci tangan dengan air yang mengalir dan sabun) setelah buang air besar, sebelum makan serta sebelum menyiapkan makanan,maka perilaku ini bermanfaat untuk meningkatkan pencapaian derajat kesehatan. Ada 8 indikator yang dipakai sebagai ukuran untuk menilai PHBS sekolah atau kegiatan siswa dalam menerapkan PHBS di sekolah, antara lain yaitu, mencuci tangan dengan air yang mengalir dan menggunakan sabun, mengkonsumsi jajanan sehat di kantin sekolah (memakan buah dan sayuran), menggunakan jamban yang bersih dan sehat serta menjaga kebersihan jamban, olahragayang teratur dan terukur, memberantas jentik nyamuk di sekolah secara rutin, tidak merokok di sekolah, menimbang berat badan dan mengukur tinggi badan setiap 6 bulan untuk memantau pertumbuhan siswa dan membuang sampah pada tempatnya (Proverawati dan Rahmawati, 2016).

Pentingnya PHBS untuk anak sekolah dikarenakan anaksekolah termasuk kelompok masyarakat yang mempunyai resiko tinggi terkena penyakit, sehingga perlu untuk menanamkan pengertian dan kebiasaan hidup sehat, kesehatan anak usia sekolah juga akan menentukan kesehatan masyarakat dan bangsa di masa depan. Dengan menerapkan PHBS 
disekolah oleh peserta didik, guru dan masyarakat lingkungan, maka akan membentuk mereka untuk memiliki kemampuan dan kemandirian dalam mencegah penyakit, meningkatkan

kesehatannya serta berperan aktif dalam mewujudkan lingkungan sekolah sehat (Maryunani, 2013). Menurut data WHO (World Health Organization) pada tahun 2015, bahwa salah satu faktor resiko meningkatnya kematian adalah dengan tidak menjalankan perilaku hidup bersih dan sehat seperti:kebersihan air yang tidak memadai, sanitasi buruk bahkan kebiasaan buang air besar di tempat terbuka, tidak mengkonsumsi makanan yang sehat, mengkonsumsi minuman beralkoholdanmerokok.

Terdapat6,8\%penduduk yang masih merokok.

Berdasarkan data WHO, angka kematian dari infeksi Covid19 lebih rendah dibandingkan dengan MERS, SARS, dan ebola. Namun, penyebaran pasien positif lebih cepat dibandingkan dengan Mers dan SARS, sehingga terjadi lonjakan jumlah penderita dalam waktu singkat. Korona yang memasuki tubuh akan menempel pada reseptor yang dikenal sebagai Angiotensin converting enzyme 2 (ACE2), kemudian virus menyuntikkan RNA-nya sehingga mengubah sel tubuh menjadi virus dan bereplikasi. Virus tersebut dapat merusak jaringan pada paru sehingga terjadi pembengkakan yang membuat kesulitan bernapas dan dapat terjadi Acute Respiratory Distress Syndrome yang mengakibatkan pasien meninggal. Selain pada paruparu, korona juga dapat menginfeksi organ lain contohnya pada saluran pencernaan. Gejala yang ditimbulkan bergantung seberapa kuatnya sistem imunitas.

Pada sistem imunitas manusia, ketika ada sel aneh yang masuk ke tubuh, akan langsung mengaktifkan respons imun bawaan dan respons imun adaptif untuk melawan virus dengan memproduksi sel pembunuh T. Orang yang lebih tua dan penderita komorbid seperti diabetes atau penyakit kronis lainnya kemungkinan besar akan mengalami gejala yang lebih berat dan biasanya 
tidak menghasilkan respons sel-T yang baik.

Hingga kini, vaksin untuk mencegah infeksi korona baru ini belum ditemukan. Karena itu, upaya yang dapat kita lakukan untuk meningkatkan sistem kekebalan yaitu menerapkan gaya hidup sehat dan mengonsumsi makanan bergizi. WHO telah mengeluarkan beberapa anjuran cara hidup sehat di masa pandemi , seperti mengonsumsi makanan sehat dan bergizi, menghindari merokok dan minuman beralkohol, berolahraga dan berjemur di pagi hari, menjaga kesehatan mental (mengelola stres dengan baik), serta menerapkan hidup bersih dengan menjaga kebersihan. Menurut data dari Kemenkes, masih banyak masyarakat Indonesia yang kekurangan gizi dan menderita diabetes. Mereka inilah yang lebih berisiko mengalami gejala yang fatal apabila terinfeksi

Menurut WHO dan para ahli bahwa diperkirakan Covid-19 tidak akan hilang dari permukaan bumi, tetap ada meskipun vaksinnya ditemukan. Virus Corona ini oleh
WHO dan para ahli tidak akan dapat dikendalikan, akan menjadi endemis yang tetap akan ada dan tetap akan berada disekitar lingkungan masyarakat. Untuk itu diperlukan perubahan dalam era new normal.

New Normal dalam bahasa Indonesia artinya kenormalan baru. Kenormalan baru merupakan keadaaan normal yang baru yang belum ada sebelumnya. New Normal adalah keadaan beradaptasi terhadap lingkungan dalam bentuk perilaku gaya hidup dan cara kerja dengan tetap mengedepankan protokol kesehatan agar masyarakat Indonesia tetap melakukan aktivitas ekonomi, tetap sehat dan terhindar dari virus Covid-19.

Kenormalan baru, sesuatu yang dirasa tidak normal tetapi di era New Normal menjadi sesuatu yang normal. Seperti sebelum era new normal, memakai masker di tempat umum adalah sesuatu yang aneh, sekarang di era kenormalan baru memakai masker adalah suatu keharusan, bila tidak memakai masker di tempat umum menjadi sesuatu yang aneh. 
II. Landasan Teori

\section{A. Penngertian Perilaku Hidup}

\section{Bersih dan Sehat}

Perilaku Hidup Bersih dan Sehat (PHBS) adalah semua perilaku kesehatan yang dilakukan atas kesadaran sehingga anggota keluarga atau keluarha dapat menolong dirinya sendiri di bidang kesehatan dan dapat berperan aktif dalam kegiatan-kegiatan kesehatan .

PHBS adalah upaya

memberikan pengalaman belajar bagi perorangan, keluarga, kelompok dan masyarakat, dengan membuka jalur komunikasi, memberikan informasi dan melakukan edukasi, guna mningkatkan pengetahuan, sikap dan perilaku, melalui pendekatan Advokasi, Bina Suasana dan Gerakan masyarakat sehingga dapat menerapkan cara-cara hidup sehat dalam rangka menjaga dan memelihara serta meningkatkan kesehatan masyarakat.(kemenkes, 2011).

Pemberdayaan masyarakat harus dimulai dari rumah tangga atau keluarga, karena rumah tangga yang sehat meupakan asset atau modal pembangunan di masa depan yang perlu dijaga, ditingkatkan dan dilindungi kesehatannya. Beberapa anggota rumah tangga mempunyai masa rawan terkena penyakit menular dan penyakit tidak , menular, oleh karena itu untuk mencegah penyakit tersebut, anggota rumah tangga perlu diberdayakan melaksanakan PHBS.

Perilaku sehat adalah pengetahuan, sikap dan tindakan proaktif untuk memelihara dan mencegah risiko terjadinya penyakit, melindungi diri dari ancaman penyakit, serta berperan aktif dalam Gerakan Kesehatan Masyarakat Perilaku Hidup Bersih dan Sehat (PHBS) adalah sekumpulan perilaku yang dipraktikkan atas dasar kesadaran sebagai hasil pembelajaran yang menjadikan seseorang atau keluarga dapat menolong diri sendiri di bidang kesehatan dan berperan aktif dalam mewujudkan derajat kesehatan masyarakatnya (Dinkes Provinsi Jawa Barat, 2008).

Jadi PHBS adalah pengetahuan, sikap dan tindakan proaktif untuk memelihara dan mencegah risiko terjadinya penyakit, melindungi diri dari ancaman 
penyakit yang dipraktikkan atas dasar kesadaran sebagai hasil pembelajaran yang menjadikan seseorang atau keluarga dapat menolong diri sendiri di bidang kesehatan dan berperan aktif dalam mewujudkan derajat kesehatan masyarakatnya.

PHBS adalah semua perilaku kesehatan yang dilakukan atas kesadaran sehingga anggota keluarga atau keluarga dapat menolong dirinya sendiri di bidang kesehatan dan berperan aktif dalam kegiatankegiatan kesehatan di masyarakat.PHBS itu jumlahnya banyak sekali, bisa ratusan. Misalnya tentang Gizi: makan beraneka ragam makanan, minum Tablet Tambah Darah, mengkonsumsi garam beryodium, memberi bayi dan balita Kapsul Vitamin A. Tentang kesehatan lingkungan seperti membuang sampah pada tempatnya, membersihkan lingkungan.Setiap rumah tangga dianjurkan untuk melaksanakan semua perilaku kesehatan.

Perilaku Hidup Bersih dan Sehat (PHBS) merupakan perilaku yang dipraktekkan oleh setiap individu dengan kesadaran sendiri untuk meningkatkan kesehatannya dan berperan aktif dalam mewujudkan lingkungan yang sehat. Perilaku Hidup Bersih dan Sehat harus diterapkan dalam setiap lini kehidupan manusia kapan saja dan dimana saja. Seperti halnya PHBS di rumah tangga/keluarga, institusi kesehatan, tempat-tempat umum, sekolah maupun di tempat kerja karena perilaku tersebut merupakan sikap dan tindakan yang akan membentuk kebiasaan seseorang untuk berperilaku sehat.

Salah satu manfaat diterapkan perilaku hidup bersih dan sehat di rumah tangga/keluarga ialah; anggota keluarga meningkat kesehatannya dan tidak mudah sakit, produktivitas anggota keluarga meningkat, dan anak tumbuh sehat dan cerdas.

\section{B. Era New Normal.}

Dalam bahasa Indonesia New Normal artinya kenormalan baru. Kenormalan baru merupakan keadaan normal yang baru yang belum ada sebelumnya. New Normal adalah keadaan adaptasi terhadap lingkungan dalam bentuk perilaku 
gaya hidup dan cara kerja dengan tetap mengedepankan protokol kesehatan agar masyarakat Indonesia tetap produkti, tetap melakukan aktivitas ekonomi, tetap sehat, dan terhindar dari irus Covid-19.

Dalam Kenormalan baru banyak yang dirasakan tidak normal tetapi di era new normal menjadi sesuatu yang normal, Seperti misalnya

1). Sebelum era new normal, memakai masker ditempat umum adalah sesuatu yang aneh, sekarang di era kenormalan baru memakai masker adalah suatu keharusan, bila tidak memakai masker di tempat umum menjadi sesuatu yang aneh.

2). Bekerja biasanya harus dikantor dan sekolah atau di kampus, rapat dan pelatihan pun harus bertemu ditempat yang disepakati tetapi sekarang di era kenormalan baru bekerja, belajar dan rapat tidak lagi dilakukan dikantor, sekolah, kampus tetapi dilakukan di rumah secara daring.

3). Sebelumnya masyarakat Indonesia setiap bertemu selalu bersalaman, tetapi di era kenormalan baru bersalaman adalah sesuatu yang tidak boleh dilakukan.

4). Berkumpul adalah sesuatu yang biasa dan normal, di era kenormalan baru berkumpul adalah hal yang harus dihindari dan dirasa aneh.

5). Ngobrol makin dekat makin akrab dan menunjukkan keseriusan, akan tetapi di era new normal jarak ngobrol minimal 1 meter, makin jauh makin bagus.

Perilaku, gaya hidup, metode kerja di era new normal tidak akan sama dengan sebelum kehadiran Covid-19. Sehingga harus merubah perilaku, cara hidup, cara kerja, dan cara berpikir di era new normal. Dengan adaptasi perilaku yang dibutuhkan di era new normal bisa sehat, panjang umur dan produktif.

\section{Perilaku Hidup Bersih dan} Sehat di Era New Normal

Kebijakan penerapan new normal yang ditetapkan oleh pemerintah membuat cara pandang yang positif dan kritis serta berperilaku yang produktif. Berikut beberapa perilaku hidup bersih dan sehat dalam menyambut New Normal Pandemi Covid-19 : 


\section{Mencuci tangan dengan} sabun dan air bersih

Perilaku hidup bersih dan sehat (PHBS) ini bertujuan untuk tetap menjaga kebersihan pribadi dan mencegah penularan dari berbagai penyakit yang ditularkan melalui tangan yang berkontaminasi kuman. Contohnya, saat seseorang yang mengidap penyakit tidak mencuci tangan setelah memegang pegangan escalator, semua yang disentuhnya akan terkontaminasi, dan jika alat yang telah terkontaminasi tersebut dipegang oleh orang lain, dan orang tersebut tidak mencuci tangan saat akan mengonsumsi makanan, maka orang tersebut akan tertular penyakit yang di bawa oleh orang yang sakit tersebut.

Maka dari itu, tetaplah mencuci tangan darimana saja kita pergi dan setiap akan mengonsumsi makanan.

2. Mengonsumsi makanan sehat
Pada masa pandemi atau rentan dengan masuknya penyakit ke dalam tubuh, maka PHBS ini menyarankan untuk banyak mengonsumsi makanan sehat seperti buah dan sayur. Buah banyak mengandung vitamin dan sayur banyak mengandung serat dan mineral. Sehingga, virus dan bakteri jahat tidak mudah masuk ke tubuh manusia dan tidak terntan terkena penyakit.

3. Mengonsumsi air putih yang cukup

Mengonsumsi air putih kurang lebih 8 gelas sehari dapat membantu tubuh menjadi lebih kuat dan tidak mudah dehidrasi serta dapat meningkatkan kesehatan tubuh manusia.

4. Olahraga secara teratur Olahraga adalah kegiatan yang sangat penting bagi tubuh manusia. Tidak hanya sehat, olahraga juga dipercaya akan membuat hidup manusia lebih bahagia. Karena olehraga dapat 
menenagkan tubuh dan fikiran manusia.

5. Istirahat yang cukup

Istirahat yang kurang dapat menyebabkan penurunan imunitas pada tubuh manusia, sehingga manusia mudah terjangkit penyakit. Minimal 7-8 jam sehari yang dibutuhkan tubuh manusia untuk beristirahat agar hidup tetap sehat

6. Membersihkan lingkungan hidup sekitar

Kebersihan lingkungan hidup adalah hal yang sangat penting untuk menghindar dari segala penyakit. Dengan menerapkan hal yang kecil seperti tidak membuang sampah sembarangan di sekitar rumah dan menjauhkan hal-hal yang tidak bersih dari sekitaran lingkungan hidup. Karena lingkungan yang bersih dapat menciptakan hidup yang sehat dan nyaman.

7. Selalu menggunakan masker ketika hendak keluar rumah
Selalu menggunakan masker ketika keluar rumah dan hendak bepergian ke tempat publik. Maker tidak hanya dapat mencegah masuknya bakteri. Namun, masker juga dapat mencegah penyebaran virus dengan melindungi bagian wajah dari Droplets seseorang yang terjangkit penyakit.

8. Terapkan Physical Distancing Menerapkan Physical Distancing sangat penting ketika kita berada di tempat publik atau keramaian. Menjaga jarak dan tidak melakukan kontak langsung dengan orang lain, kecuali jika ada kepentingan. Karena jika seseorang sudah terjangkit penyakit, dan orang yang lainnya berkontak langsung dengan orang tersebut, maka dengan mudah orang-orang lainnya dapat tertular penyakit.

9. Bersihkan permukaan benda dengan disinfektan Untuk barang atau benda yang sering disentuh dengan 
banyak orang baik di rumah ataupun diluar rumah, sebaiknya benda-benda tersebut dapat dibersihkan dengan disinfektan secara rutin. Tidak hanya barang ataupun benda milik seseorang, tangan juga salah satu media penyebaran bakteri atau penyakit yang harus sering dibersihkan dengan hand sanitizer agar tidak mudah terkena atau tertular penyakit.

\section{Konsumsi Pangan}

Konsumsi Pangan Penerapan pola makan sehat merujuk pada pedoman gizi seimbang seperti pemilihan, pengolahan, dan konsumsi pangan sehat berperan menguatkan sistem imunitas, serta dapat mengurangi risiko penyakit. Pemilihan makanan sebaiknya mengadung gizi lengkap, yang terdiri dari makronutrien (karbohidrat, protein, lemak) dan mikronutrien (vitamin dan mineral). Akan lebih efektif ditunjang pengolahan pangan secara tepat dengan memasak bahan pangan secara matang sehingga menjadi pangan aman dan higienis. Pada masa Pandemi, ada baiknya mengonsumsi makanan kaya kandungan antioksidan, seperti sayuran dan buah-buahan, untuk membantu proses pencegahan radikal bebas yang dapat mengganggu kerja sistem imun. Produk herbal yang berasal dari rempah-rempah seperti jahe, kunyit, temulawak mengandung beragam senyawa bioaktif yang telah diakui mempunyai efek baik bagi tubuh. Senyawa bioaktif tersebut dapat berperan sebagai antioksidan, antiinflamasi, immunomodulator, antimikroba, dan antivirus, sehingga senyawa tersebut berpotensi untuk menghambat replikasi virus.

Efek mengonsumsi produk herbal dapat dipengaruhi dari takaran konsumsi yang tepat, penyerapan senyawa oleh tubuh, dan jenis senyawa bioaktifnya, karena senyawa tersebut hanya dapat bekerja pada jenis virus tertentu. Hingga kini, belum adanya penelitian tentang suatu senyawa tertentu yang efektif sebagai antivirus korona. Maka itu, sebagai konsumen, harus pintar dalam memilih produk herbal 
yang beredar di pasaran berupa jamu, obat herbal terstandar OHT, dan fitofarmaka. Fitofarmaka adalah produk yang paling aman dikonsumsi karena sudah melalui uji praklinik dan klinik.

Selain itu, banyak masyarakat yang lebih memilih mengonsumsi suplemen agar daya tahan tubuh kuat. Namun, sebenarnya suplemen hanya diperlukan bagi orang yang tidak mengonsumsi jumlah vitamin dan mineral yang diperlukan oleh tubuh. Konsumsi suplemen hanya diperlukan pada orang yang menderita penyakit tertentu, ibu hamil, olahragawan, tenaga medis dan praktisi yang menangani wabah.

Penggunaan suplemen dalam kondisi biasa seharusnya tidak diperlukan, asalkan kebutuhan nutrisi dari makanan tercukupi dengan ditunjang gaya hidup sehat. Penerapan gaya hidup sehat secara individu seperti rutin berolahraga, mengonsumsi makanan bergizi, tidur cukup, dan mengelola stres dengan baik, serta menjaga kebersihan diri dan lingkungan akan menjaga imunitas untuk menangkal masuknya virus korona. Oleh karena itu, di masa pandemic Covid-19 yang masih berlangsung saat ini, marilah kita menerapkan gaya hidup bersih dan sehat untuk dapat menangkalnya.

III. Identifikasi dan Perumusan Masalah

Perilaku Hidup Bersih dan Sehat (PHBS) merupakan langkah yang harus dilakukan untuk mencapai kesehatan yang optimal bagi setiap orang. Kondisi sehat tidak bisa langsung jadi, tetapi harus senantiasa diupayakan dari yang tidak sehat menjadi hidup yang sehat serta menciptakan lingkungan yang sehat. Upaya ini harus dimulai dari menanamkan pola pikir sehat kepada masyarakat yang harus dimulai dan diusahakan oleh diri sendiri. Upaya ini adalah untuk mewujudkan kesehatan masyarakat setinggitingginya sebagai satu investasi bagi Kualitas Sumber Daya Manusia yang produktif. Dalam mengupayakan perilaku ini dibutuhkan komitmen bersama-sama saling mendukung dalam meningkatkan kesehatan masyarakat khususnya keluarga sehingga pembangunan kesehatan dapat tercapai maksimal. 
Namun pada kenyataannya di kawasan pedesaan perhatian masyarakat akan pentingnya melakukan PHBS masih minim, khususnya masyarakat di Desa Jatimulyo, Kecamatan Jenggawah Kabupaten Jember Propinsi Jawa Timur merupakan daerah dimana masyarakatnya masih kurang pengetahuan dan informasi sehingga masalah kesehatan masih menjadi masalah yang cukup besar, Menurut data Puskesmas Jatimulyo mulai Januari 2019 sampai Nopember 2019 ada yang terkonfirmasi Covid19 sebanyak 3 orang, Probable (orang yang diyakini sebagai suspek dengan ISPA berat atau gagal nafas akibat aveoli paru-paru penuh cairan atau meninggal dengan gambaran klinis yang meyakinkan COVID-19 dan belum ada hasil pemeriksaan laboratorium RT-PCR) sebanyak 6 orang. Ini berarti masih kurangnya kesadaran dan pentingnya menjaga Perilaku Hidup Bersih dan Sehat.

$$
\text { Berdasarkan }
$$

kepentingan dan kebutuhan masyarakat dalam merealisasikan PHBS serta keadaan masyarakat Desa Jamulyo yang masih minim kepeduliannya akan kesehatan pada masa fase new normal, maka dibutuhkan program Sosialisasi Perubahan Perilaku Hidup Bersih dan Sehat Era New Normal. Yang diharapkan dapat meningkatkan pengetahuan, kesadaran, kemauan dan kemampuan masyarakat Desa Jatimulyo untuk melakukan Perilaku Hidup Bersih dan Sehat dalam meningkatkan mutu hidup serta meningkatkan kesehatan masyarakat dengan indikator angka terkonfirmasi Covid-19 menurun. Program ini di khususkan kepada Penerima Program Keluarga Harapan di Desa Jatimulyo Kecamatan Jenggawah Kabupaten Jember.

\section{Tujuan dan Manfaat Program}

Mengacu pada permasalahan yang dihadapi oleh Kelompok Penerima Program Keluarga Harapan di Desa Jatimulyo Kecamatan Jenggawah tentang Perilaku Hidup Bersih dan Sehat di Era New Normal, maka tujuan dilaksanakannya pengabdian masyarakat ini adalah sebagai bentuk transfer pengetahuan tentang caracara penerapan perubahan perilaku 
sebagai upaya preventif Covid-19. Pengetahuan perilaku hidup bersih dan sehat di era new normal ditujukan kepada Kelompok Penerima Program Keluarga Harapan sebagai pelopor adaptasi baru di Desa Jatimulyo Kecamatan Jenggawah.

\section{Manfaat Kegiatan}

Pada nantinya diharapkan membawa manfaaat kepada Kelompok PKH bisa mengajak dan ditiru oleh masyarakat pada umumnya untuk melakukan perubahan perubahan dalam berperilaku hidup bersih dan sehat di era New Normal.

\section{Kerangka Pemecahan Masalah} Pengabdian kepada masyarakat merupakan kewajiban seorang tenaga pendidik, dalam hal ini adalah dosen. Setiap dosen harus melaksanakan tri dharma yang salah satunya adalah pengabdian kepada masyarakat. Dosen harus mampu melihat permasalahan-permasalahan yang ada pada masyarakat. Permasalahan yang ada harus dicarikan solusi permasalahannya.

\section{Khalayak Sasaran}

Program pengabdian kepada masyarakat dilaksanakan di Balai Desa Jatimulyo Kecamatan Jenggawah Kabupaten Jember karena disana sebagai penerima Program Keluarga Harapan (PKH) terbanyak di kecamatan Jenggawah.

Melihat kondisi seperti itu, dosen membuat program pengabdian untuk trasfer pengetahuan kepada penerima $\mathrm{PKH}$ tentang bagaimana cara merubaha perilaku hidup bersih dan sehat di era new normal Setidaknya ada dua alasan kenapa harus penerima PKH yang digunakan sebagai peserta program. Alasan pertama adalah agar Penerima PKH bisa sebagai pelopor adaptasi baru. Alasan yang kedua adalah agar Penerima PKH dapat merubah kebiasaan baru di dalam anggota keluarganya..

\section{Metode Kegiatan}

Metode dalam program pengabdian ini adalah dengan model ceramah berbentuk seminar classes. Pemateri melaksanakan tatap muka dan berkomunikasi langsung dengan para peserta. Kegiatan ini dihadiri 
oleh 16 peserta Penerima PKH Desa Jatimulyo. Meskipun kegiatan ini berlangsung dengan cara tatap muka, tetapi protokol kesehatan masih tetap dijalankan mengingat kondisi pandemi Covid-19 masih belum berakhir.

Para peserta diukur suhu menggunakan thermo gun sebelum memasuki ruangan. Thermo gun merupakan alat ukur suhu atau termometer dengan metode non kontak fisik. Pengukuran suhu dilakukan karena salah satu gejala dari infeksi Covid-19 adalah peningkatan suhu tubuh (demam). Peserta yang memiliki suhu badan diatas 37,7 derajat celsius tidak diperbolehkan mengikuti kegiatan. Dari keseluruhan peserta yang mengikuti program ini tidak ada yang memiliki suhu tubuh diatas 37 , dengan demikian semua peserta dapat mengikuti rangkaian kegiatan. Protokol kesehatan lain yang harus dipatuhi adalah seluruh peserta wajib menggunakan masker. Tempat duduk yang disediakan juga diatur jarak sehingga para peserta tidak saling berdekatan.
Program pengabdian ini dilaksanakan pada tanggal 05 Desember 2020 pada pukul 08.00 WIB, bertempat di Balai Desa Jatimulyo Kecamatan Jenggawah Kabupaten Jember Provinsi Jawa Timur. Tema kegiatan yang diambil adalah tentang sosialisasi Perilaku hidup bersih dan sehat era new normal di masa pandemi, sebagai upaya preventif penularan Covid-19.

\section{Evaluasi Kegiatan}

Program pengabdian kepada masyarakat yang dilaksanakan dosen dan mahasiswa sebagai perwujudan Tri Dharma berjalan dengan baik. Peserta PKH sebelumnya sudah paham dan mengetahui tentang pandemi Covid-19 tetapi dengan identifikasi masih banyak yang belum menggunakan protokol kesehatan dilingkungan. Sekarang menjadi lebih memahami. Karena hal ini membutuhkan proses mengidentifikasi, pengenalan dan keterbiasaan dalam melakukan protokol kesehatan. Karena satusatunya cara yang paling efektif adalah dengan cara mencegah yaitu 
menerapkan perilaku hidup bersih dan sehat.

Setelah pengabdian ini selesai dilakukan, bukan berarti program ini telah berakhir. Pemantauan juga tetap dilakukan setelah mitra menerima pengetahuan (teori) dari hasil sosialisasi Perilaku Hidup Bersih dan Sehat Era New Normal. Sedangkan untuk keberlanjutan kegiatan akan dilakukan dengan cara yaitu dosen pengabdian akan berkomunikasi kepada semua pihak. Pihak pertama adalah Pendamping Program Keluarga Harapan DesaJatiimulyo, pihak kedua Penerima Program Keluarga Harapan. Apakah Sosialisasi Perubahan perilaku hidup bersih dan sehat era new normal sudah bisa dilakukan dengan baik setelah diadakan program pengabdian.

Program pengabdian kepada masyarakat yang dilaksanakan dosen dan mahasiswa sebagai perwujudan Tri Dharma berjalan dengan baik. Peserta PKH sebelumnya sudah paham dan mengetahui tentang pandemi Covid-19 tetapi dengan identifikasi masih banyak yang belum menggunakan protokol kesehatan dilingkungan. Sekarang menjadi lebih memahami. Karena hal ini membutuhkan proses mengidentifikasi, pengenalan dan keterbiasaan dalam melakukan protokol kesehatan . Karena satusatunya cara yang paling efektif adalah dengan cara mencegah yaitu menerapkan perilaku hidup bersih dan sehat.

Setelah pengabdian ini selesai dilakukan, bukan berarti program ini telah berakhir. Pemantauan juga tetap dilakukan setelah mitra menerima pengetahuan (teori) dari hasil sosialisasi Perilaku Hidup Bersih dan Sehat Era New Normal.

Sedangkan untuk keberlanjutan kegiatan akan dilakukan dengan cara yaitu dosen pengabdian akan berkomunikasi kepada semua pihak. Pihak pertama adalah Pendamping Program Keluarga Harapan DesaJatiimulyo, pihak kedua Penerima Program Keluarga Harapan. Apakah Sosialisasi Perubahan perilaku hidup bersih dan sehat era new normal sudah bisa dilakukan dengan baik 
setelah diadakan program pengabdian.

\section{DAFTAR PUSTAKA}

Kemenkes RI. 2011. Panduan Pembinaan dan Penilaian Perilaku Hidup Bersih dan Sehat di Rumah Tangga.

Prihantama. 2020. Perilaku Hidup Bersih dan Sehat Cegah Covid$19 . \quad$ https://dinkesslemankab.go.id/perilakuhidup-bersih-dan-sehat-cegahcovid-19.html. Diakses pada tanggal 20 November 2020 pada pukul 17.00 WIB.

Siahaaan, Elisabet. 2020. Perubahan Perilaku Sumber Daya Manusia yang Produktif di Era $N w$ Normal.

https://waspada.co.id/2020/08/p erubahan-perilaku-sumberdaya-manusia-yang-produktifdi-era-ner-normal/. Diakses pada tanggal 20 Nopember 2020 pada pukul 16.00 WIB.

Rahardani, Armita. 2019. 10 Perilaku Hidup Bersih dan Sehat di Rumah. Sudahkah Anda Lakukan?. https://www.sehatq.com/artikel /perilaku-hidup-bersih-dansehat-dalam-rumah-tangga.

Diakses pada tanggal 20 Nopember 2020 pada pukul 16.50 WIB. 